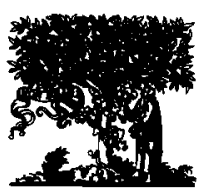

PHYSICS

OFTHE EARTH

AND PLANETARY

INTERIORS

ELSEVIER

Physics of the Earth and Planetary Interiors 92 (1995) 245-260

\title{
Magnetostratigraphy of a Lower-Middle Triassic boundary section from Chios (Greece)
}

\author{
G. Muttoni ${ }^{\text {a,b, * }}$, D.V. Kent ${ }^{\text {b }}$, M. Gaetani ${ }^{\text {a }}$ \\ ${ }^{a}$ Dipartimento Scienze della Terra, Universitá degli Studi di Milano, Milan, Italy \\ ${ }^{\mathrm{b}}$ Lamont-Doherty Earth Observatory, Columbia University, Palisades, NY 10964, USA
}

Received 30 June 1994; revision accepted 3 March 1995

\begin{abstract}
The Marmarotrapeza Formation at Chios Island (northern Aegean Sea, Greece) is renowned for its Lower-Middle Triassic boundary sections in a marine Tethyan setting. Two sections have been sampled bed by bed to develop a magnetostratigraphic framework for the ammonoid and conodont biostratigraphy. The boundary sections occur within a lower normal $\left(\mathrm{A}^{+}\right)$-reverse $\left(\mathrm{B}^{-}\right)$-upper normal $\left(\mathrm{C}^{+}\right)$polarity sequence. The Lower-Middle Triassic boundary, placed at the first occurrence of the ammonoid genera Aegeiceras ugra Diener, Paracrochordiceras spp., Paradanubites depressus Fantini Sestini and Japonites sp., and close to the first appearance of the conodont species Gondolella timorensis Nogami, occurs in normal polarity zone Chios $\mathrm{C}^{+}$. The overall mean direction of the reversal-bearing characteristic component, whose early acquisition is suggested by a tilt test, is $D=271.2^{\circ}, I=33.2^{\circ}$ $\left(\alpha_{95}=11.7^{\circ}, k=112.5, N=3\right)$. The inferred paleolatitude of the sampling sites is about $18^{\circ} \mathrm{N}$, consistent with either an African or stable European affinity, although the declinations suggest large-scale counter-clockwise rotations with respect to Africa or stable Europe since the Early-Middle Triassic.
\end{abstract}

\section{Introduction}

The goal of global stratigraphy is to synthesize chronostratigraphic data from different geological environments and faunistic provinces into a common time scale. In this perspective, magnetostratigraphy is an ideal tool for correlations between environments that have few biostratigraphic elements in common. For times before the Late Jurassic, Cretaceous and Cenozoic, for

\footnotetext{
${ }^{*}$ Corresponding author.
}

which the pattern of geomagnetic polarity reversals has been well established from analyses of marine magnetic anomalies, the geomagnetic polarity time scale (GPTS) is not well known and its improvement requires assembling continuous and fossiliferous land sections suitable for paleomagnetic analysis. The paleomagnetic research reported here is focused on the Tethyan LowerMiddle Triassic Marmarotrapeza Formation of Chios Island (Greece). Two sections were sampled at the Marathovouno locality to provide a magnetostratigraphic framework for the ammonoid and conodont biostratigraphy across the Lower-Middle Triassic boundary. A third site 


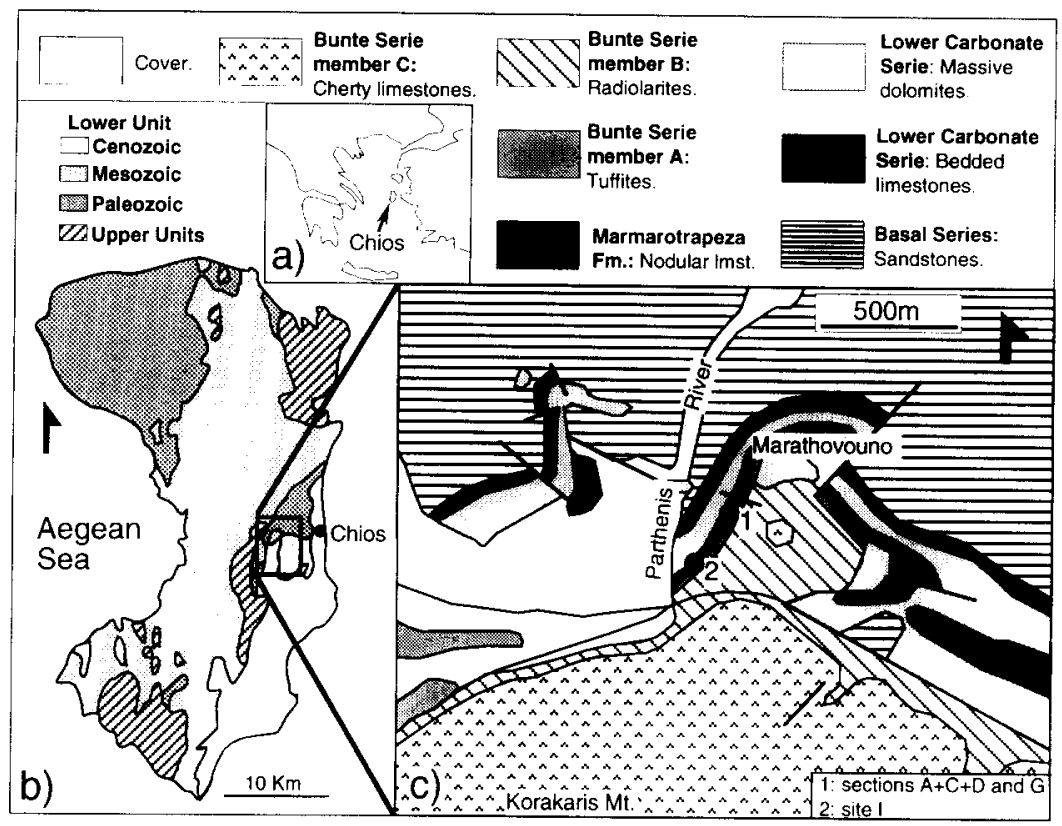

Fig. 1. (a) Geographic location and (b) simplified geological map of Chios Island (after Gaetani et al., 1992); (c) geological sketch map of the Marathovouno hillock area (after Lazzaroni, 1991).

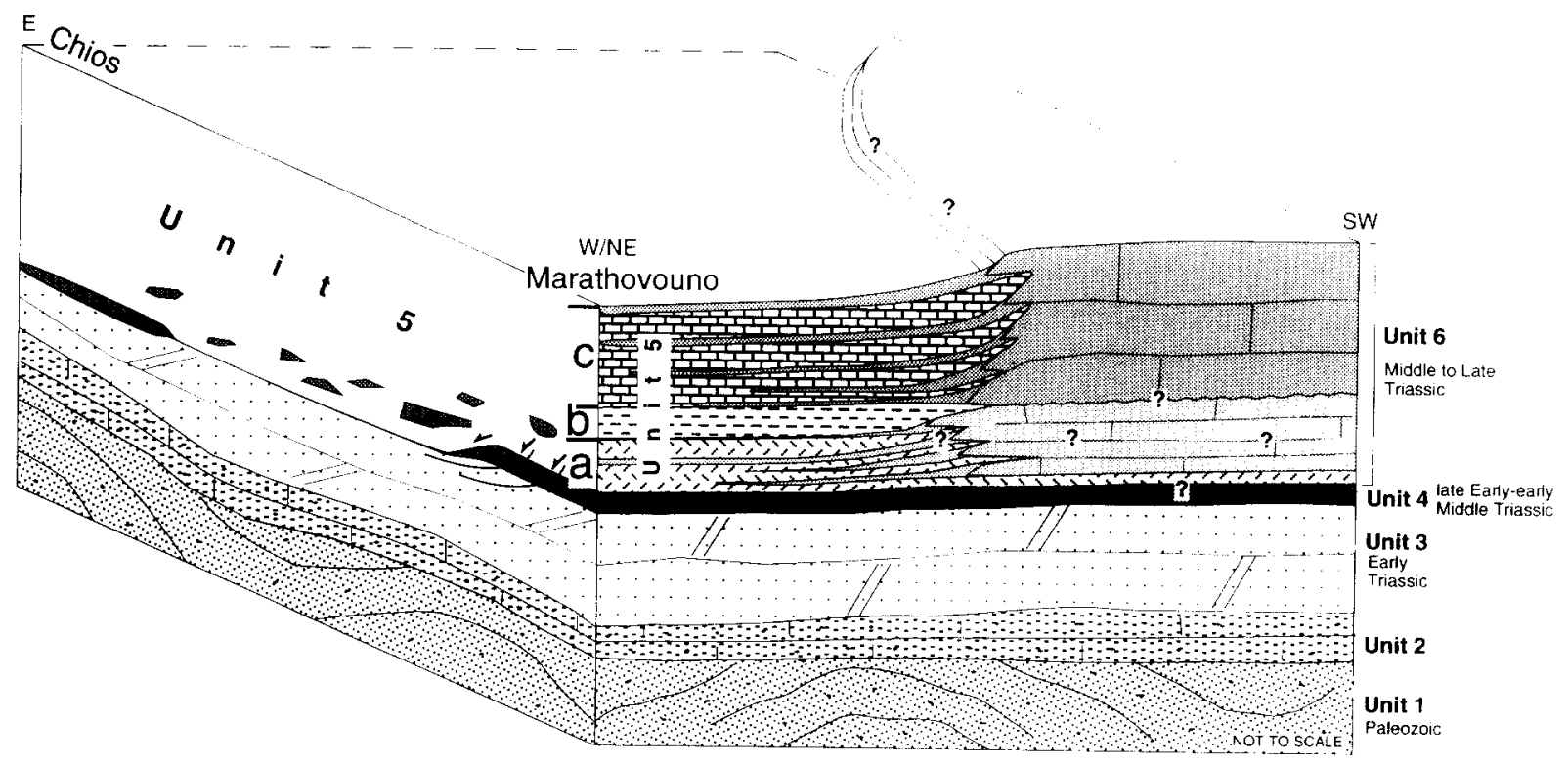

Fig. 2. Block-diagram of Paleozoic to Late Triassic sedimentation of the Marathovouno area. The east-west profile (from the town of Chios to the Marathovouno hillock) is from Gaetani et al. (1992). The NE-SW profile strikes from the Marathovouno hillock to a generic point in the 'Triassic carbonate platform'. 
with a different bedding attitude was also sampled to constrain the ages of the magnetizations with a tilt test.

\section{Geological setting}

The island of Chios, located in the northern Aegean Sea (nominal coordinates of sampling sites $38.2^{\circ} \mathrm{N}, 26.0^{\circ} \mathrm{E}$ ), consists of two structurally superposed tectonic units (Gaetani et al., 1992) (Fig. 1). The upper unit is poorly developed and contains few Triassic age rocks, whereas the lower unit (the 'autochthonous' of Besenecker et al.
(1968, 1971)) contains a thick Triassic sedimentary sequence showing affinities with the Pelagonian zone of mainland Greece. The Lower-Middle Triassic boundary sections crop out in the lower tectonic unit a few kilometers west of the town of Chios, at the Marathovouno hillock. This area has been mapped most recently by Lazzaroni (1991) (Fig. 1). According to Gaetani et al. (1992), six sedimentary units can be recognized (Fig. 2). The Marmarotrapeza Formation of Unit 4 consists of up to $18 \mathrm{~m}$ of decimeter-thick beds of red nodular limestones and red marls containing a diversified fauna (ammonoids, conodonts, pelagic bivalves and foraminifers). At the

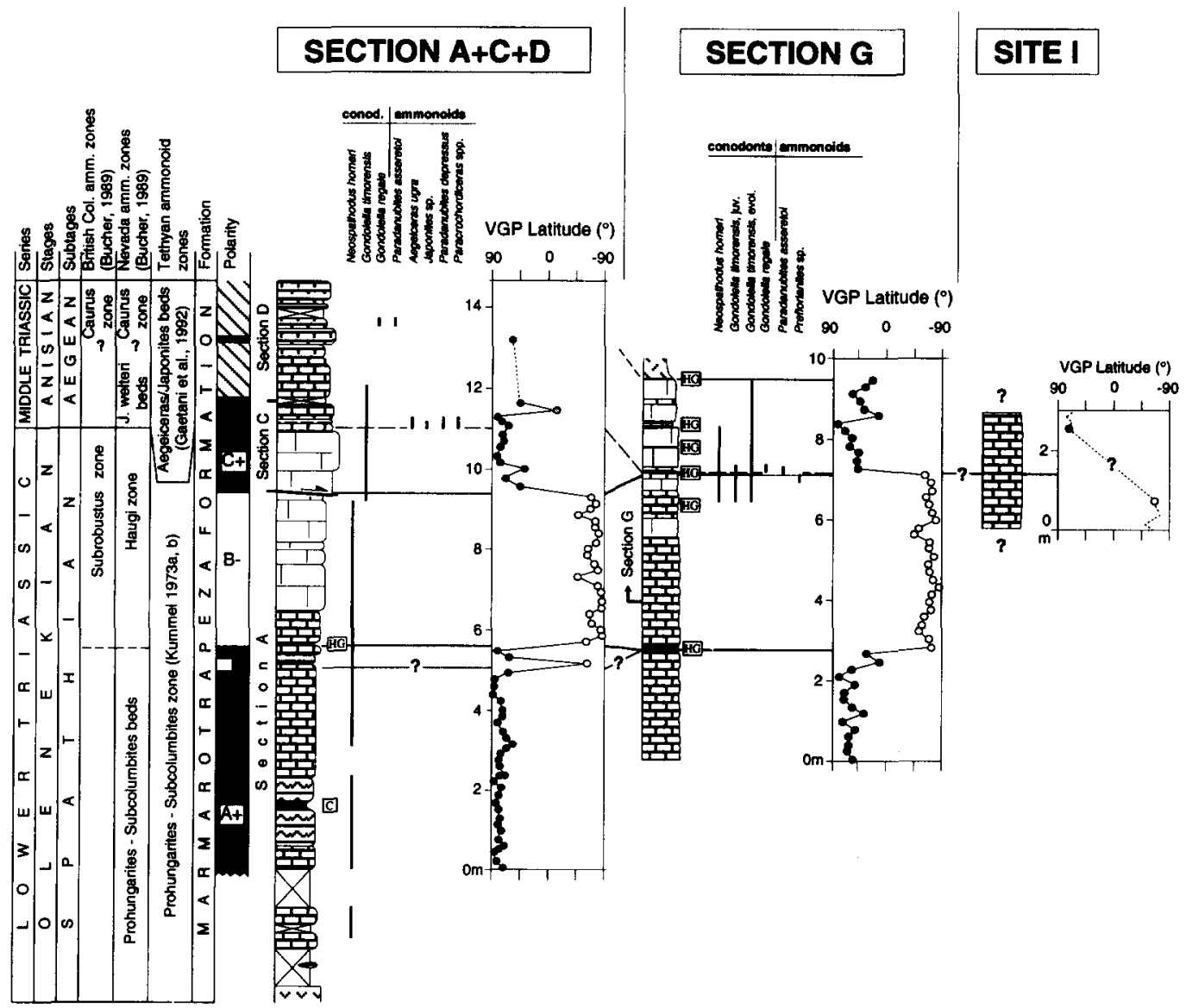

Fig. 3. Lower-Middle Triassic boundary Sections A + C + D and G of Gaetani et al. (1992). Virtual geomagnetic pole latitudes for $\mathrm{C}$ component directions plotted as function of stratigraphic thickness. Magnetic polarity zones are shown by filled bars for normal polarity and open bars for reversed polarity. The occurrence or appearance of the most important ammonoids and conodonts used to define the boundary is indicated by bold lines. The Early-Middle Triassic boundary based on ammonoids falls within polarity zone $\mathrm{C}^{+}$. In the lithology logs, HG stands for hard ground and $\mathrm{C}$ for condensed interval. 
Marathovouno hillock, the Anisian portion of the Marmarotrapeza Fm. occupies the uppermost 2$3.5 \mathrm{~m}$ of the section (Fig. 3) and is directly overlain by the Variegated Series of Unit 5 (Bunte Serie of Besenecker et al. (1968)), consisting of green tuffs, radiolarites, grey cherty limestones, calcareous breccia and calcarenites. Unit 5 is coeval with a carbonate platform (Unit 6) across a well-preserved platform margin. In the Marathovouno hillock area, Units 5 and 6 are Anisian to Norian-?Rhaetian in age (Muttoni and Rettori, 1994).

The Lower-Middle Triassic Marmarotrapeza Formation has long been the subject of stratigraphic research, essentially for its diversified paleontological content (e.g. Renz and Renz, 1948). Bender (1970) described a Lower Triassic to lowermost Anisian (lowest stage of the Middle Triassic) ammonoid and conodont faunal succession at the Marathovouno hillock, where he measured and sampled three sections, CMI, CMII and CMIII. Assereto (1974) improved the ammonoid biostratigraphy and proposed the Marathovouno hillock, and in particular Section CMII, as the type locality for the Aegean, the lowermost substage of the Anisian. Assereto et al. (1980), Fantini Sestini (1981) and Gaetani et al. (1992) successively resampled the sections and better defined the biostratigraphy across the Early-Middle Triassic boundary. The Chios sections were also discussed by Wang (1985) and Bucher (1989) in their papers on the Early-Middle Triassic boundary and lowermost Anisian ammonoids.

Several tectonic events occurred in the Chios region. As potential source mechanisms for magnetic overprinting, they can be informally grouped into two tectonic cycles: 'Hellenic' and 'Anatolian' cycles.

The Hellenic tectonic cycle is directly connected to the formation of the Hellenides. Besenecker et al. (1968) reported a thrusting event at Chios dated to the Late Cretaceous, mainly in analogy with western Anatolia. The succeeding Eocene deformation, related to the emplacement of the Pelagonian Nappes, widely affected the central and eastern Aegean (internal Hellenides), to which the Chios area belongs (Jacobshagen et al., 1978). Most of the deformation at the
Marathovouno hillock was probably caused by Late Cretaceous-Eocene compression.

During the Anatolian tectonic cycle, compressive deformation reached the external Hellenides in the Middle Miocene, and in western Anatolia and the northeastern Aegean, Oligo-Miocene andesitic volcanic activity occurred (Jacobshagen et al., 1978). At Chios, the age of volcanism ranges from 17 to $14.3 \mathrm{Ma}$ and in the Karaburun peninsula from 21.3 to $12.7 \mathrm{Ma}$ (Fytikas et al., 1984). Overlapping in time with the Oligo-Miocene volcanism was an important Neogene to present tensional activity that affected western Anatolia through the formation of a dense pattern of normal faults and grabens. As a general consequence, a complex history of local tectonic rotations, sometimes in opposite senses in adjacent blocks, occurred since $20 \mathrm{Ma}$ (Early Miocene) in western Anatolia (Kissel et al., 1987). Some of these rotations post-date the most recent volcanic products of the Izmir region, dated to $7 \mathrm{Ma}$, and belong to the neotectonic regime (Kissel et al., 1987). Recent paleomagnetic analysis from the south of Chios, suggesting the occurrence of about $25^{\circ}$ counter-clockwise rotation since the Miocene (Kondopoulou et al., 1993), can be interpreted in this framework of local tectonic rotations. Finally. short periods of weak compression during the Pleistocene locally interrupt the Neogene distention in western Anatolia (Zanchi et al., 1990), although no data are at present available for Chios to document the most recent tectonic activity.

\section{Paleomagnetic analysis}

Section $\mathrm{A}+\mathrm{C}+\mathrm{D}$ and Section $\mathrm{G}$ of Gaetani et al. (1992), equivalent to Sections CMII and CMI, respectively, of Bender (1970), were sampled stratigraphically with an average sampling interval of $25 \mathrm{~cm}$. Site I has a different bedding attitude and has been sampled in the hope of performing a tilt test, even though this third site has few magnetostratigraphic implications. Samples were taken with a portable water-cooled petrol-engined drill and oriented by means of a magnetic compass. From each core sample (of 2.5 
cm diameter) one, or more rarely two, standard $11 \mathrm{~cm}^{3}$ specimens were cut, yielding a total of 232 specimens for analysis. All the specimens were subjected to complete stepwise thermal demagnetization of natural remanent magnetization (NRM). Mineral alterations after each heating step were monitored with a Bartington Susceptibility Meter MS2 (Bartington Instruments Ltd., Oxford, UK). Remanence measurements were performed in a $2 \mathrm{G}$ three-axis cryogenic magnetometer (2G Enterprises, Mountain View, CA, USA) located in a magnetically shielded room. Principal component analysis (Kirschvink, 1980) was applied to determine the component directions, chosen by inspection of vector end-point demagnetograms. Mean directions were determined with standard Fisher statistics.

Vector end-point demagnetograms reveal three progressively isolated components at Section $\mathrm{A}+$ C + D (Fig. 4) and Section G (Fig. 5). A presentday field or spurious component, highly scattered but typically with steep positive inclinations, is removed first to $200^{\circ} \mathrm{C}$, then a ' $\mathrm{B}$ ' component with north-westerly declinations and positive inclinations is resolved between 300 and $600^{\circ} \mathrm{C}$, and finally a dual polarity northwest-and-down or southeast-and-up ' $C$ ' component regarded as characteristic is revealed between $625-650^{\circ}$ and $680^{\circ} \mathrm{C}$. At Site I (Fig. 5), the B component was always resolved, although the characteristic $\mathrm{C}$ component was isolated in only two specimens.

This general picture was occasionally complicated by the occurrence of highly scattered north-south and east-west bipolar trajectories in the unblocking temperature spectra normally occupied either by the $\mathrm{B}$ or the $\mathrm{C}$ components. Owing to their uncommonness and poor statistical definition, these magnetizations are not discussed further.

The thermal decay of the NRM, with intensities ranging from about 1 to $60 \mathrm{~mA} \mathrm{~m}^{-1}$, indicates maximum unblocking temperatures consistent with hematite as the principal carrier of the remanence. The characteristic component has
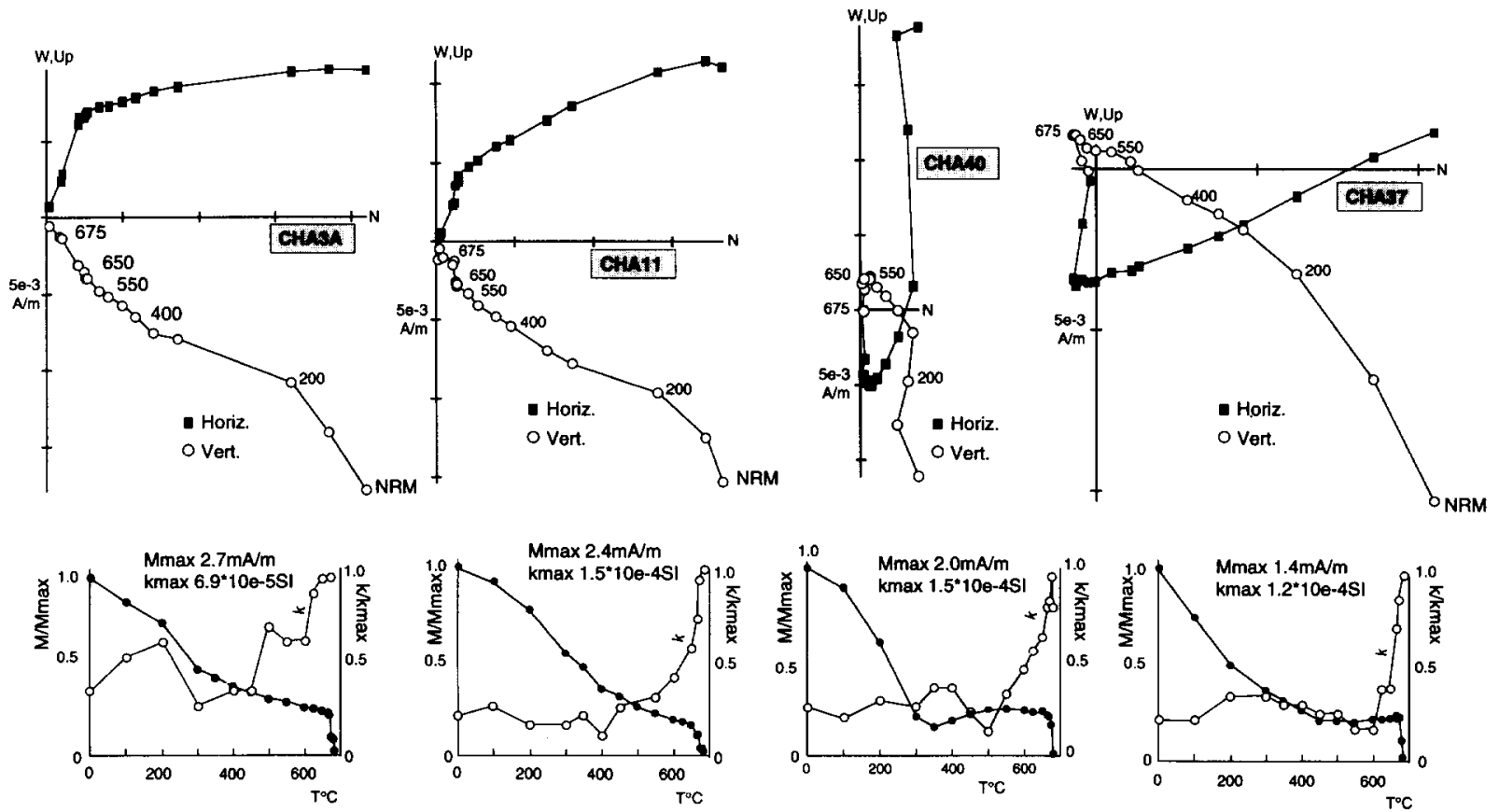

Fig. 4. Zijderveld demagnetograms and thermal decay of NRM, illustrating typical behaviors observed at Section $A+C+D$. Closed symbols are projections onto the horizontal plane and open symbols are projections onto the vertical plane. All diagrams are in in-situ coordinates. 
unblocking temperatures closely distributed between 650 and $680^{\circ} \mathrm{C}$. Initial (volume) susceptibility is generally very low, typically about $10^{-5}-10^{-4}$ SI. A slight increase in susceptibility is sometimes observed above $500^{\circ} \mathrm{C}$, owing to the formation of a secondary magnetic phase during heating, but this did not seem to affect the recovery of the characteristic remanence.

The $\mathrm{B}$ component sample directions are well clustered at Site I $(k=98)$, where the C component was found in only two specimens, but much less so in Section $\mathrm{G}(k=21)$ and Section $\mathrm{A}+\mathrm{C}$ $+\mathrm{D}(k=10)$, where the $\mathrm{C}$ components were more readily isolated (Fig. $6(\mathrm{~A})$ ). Although the grouping of the $\mathrm{B}$ component site means with no tilt correction is not significantly different from that after full tilt correction, a secondary origin of the $\mathrm{B}$ component is nevertheless indicated by the significantly better grouping of the site means at partial $(30 \%)$ rather than full $(100 \%)$ tilt correction (Fig. 6(B); Table 1). The overall mean direction after $30 \%$ tilt correction is $D=331.2^{\circ}, I=$ $34.2^{\circ}\left(\alpha_{95}=7.9^{\circ}, k=243, N=3\right)$ and indicates a paleolatitude of $19^{\circ} \mathrm{N}$ for the syn-folding magnetization.

The $\mathrm{C}$ component has dual polarity at all three sites (Fig. 7(A); Table 1). The Fisher-distributed positive and negative mean directions deviate from antipodality by $16.7^{\circ}$ and $6.4^{\circ}$ at Sections $\mathrm{A}+\mathrm{C}+\mathrm{D}$ and $\mathrm{G}$, respectively. These departures may be attributed to partial contamination by the B component. Nevertheless, the tilt corrected positive and negative mean directions of Sections $\mathrm{A}+\mathrm{C}+\mathrm{D}$ and $\mathrm{G}$ and the two directions of Site I collectively pass the reversal test at the $95 \%$ level of confidence (Class B; McFadden and McElhinny, 1990) (Fig. 7(B)).

The precision parameter of the three site-mean $\mathrm{C}$ directions increases with tilt correction to become a factor of 9.8 greater after essentially full (95-100\%) correction for bedding tilt (Fig. 7(C)). Bearing in mind that Site I is represented by only two sample directions, the tilt test on the site means is positive at the $95 \%$ level of confidence

\section{SECTION G}
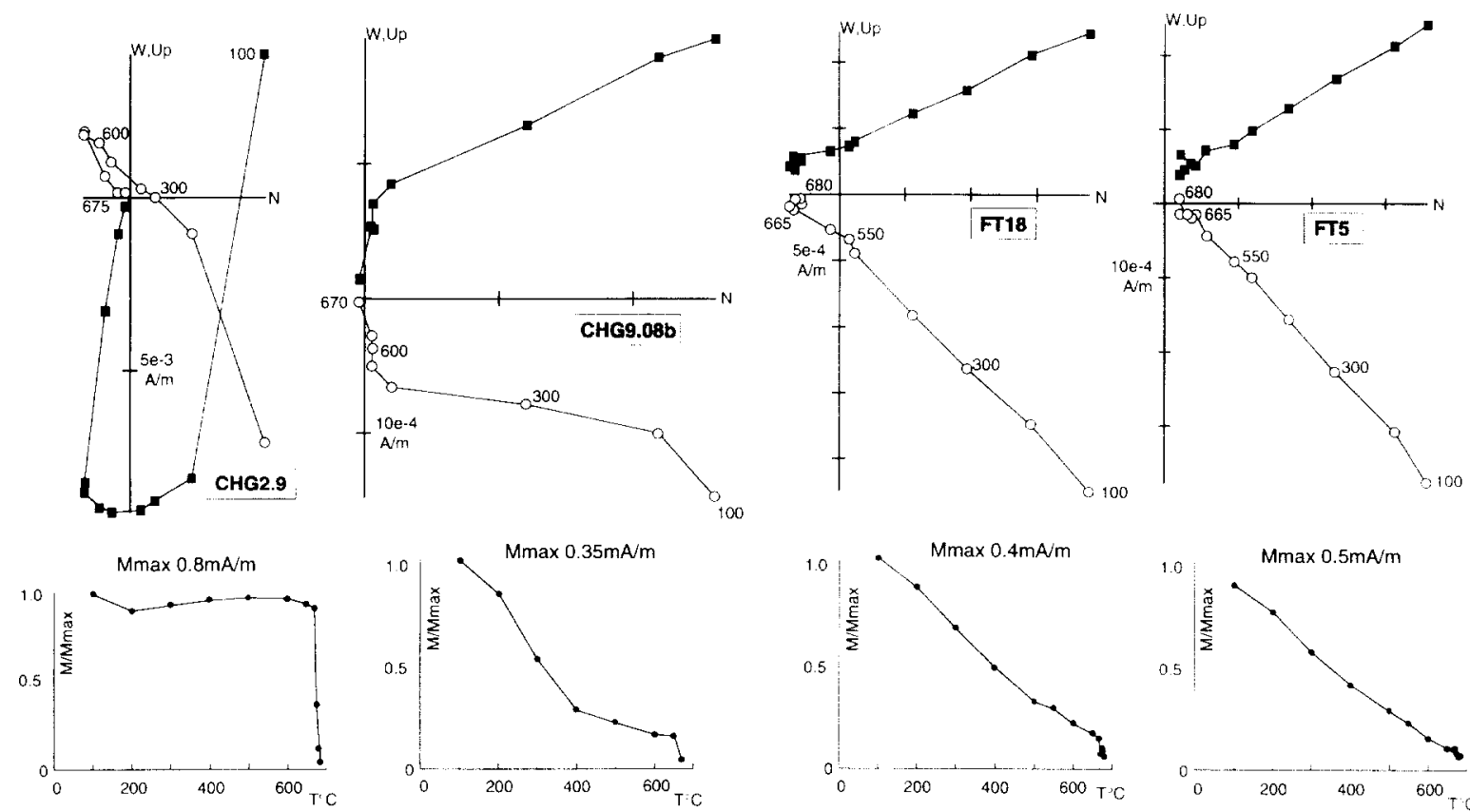

Fig. 5. Zijderveld demagnetograms and thermal decay of NRM, illustrating typical behaviors observed at Section G and Site 1 . Conventions as in Fig. 4. 
according to the criteria of McFadden and Jones (1981), suggesting an early acquisition of the C component. The overall mean direction after full tilt correction is $D=271.2^{\circ}, I=33.2^{\circ}\left(\alpha_{95}=11.7^{\circ}\right.$, $k=112.5, N=3$ ) and indicates a paleolatitude of $18^{\circ} \mathrm{N}$ for the characteristic magnetization.

Thermal demagnetization of isothermal remanent magnetization (IRM) according to the

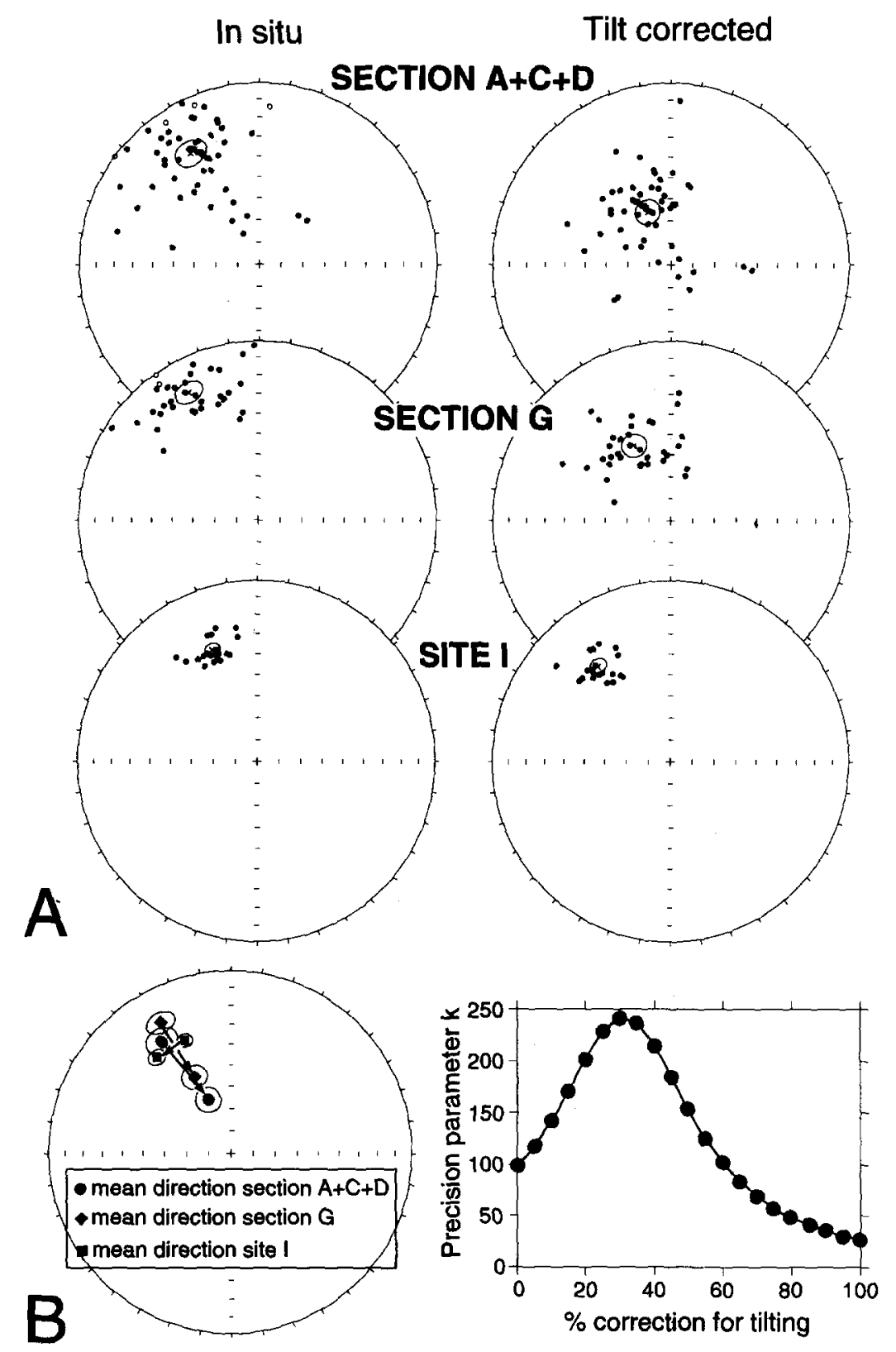

Fig. 6. Equal-area projections before (in situ) and after bedding tilt correction of (A) the B component directions, and (B) site-mean $B$ component directions from Sections $A+C+D$ and $G$, and Site $I$, with variation in $k$ value with incremental unfolding. 


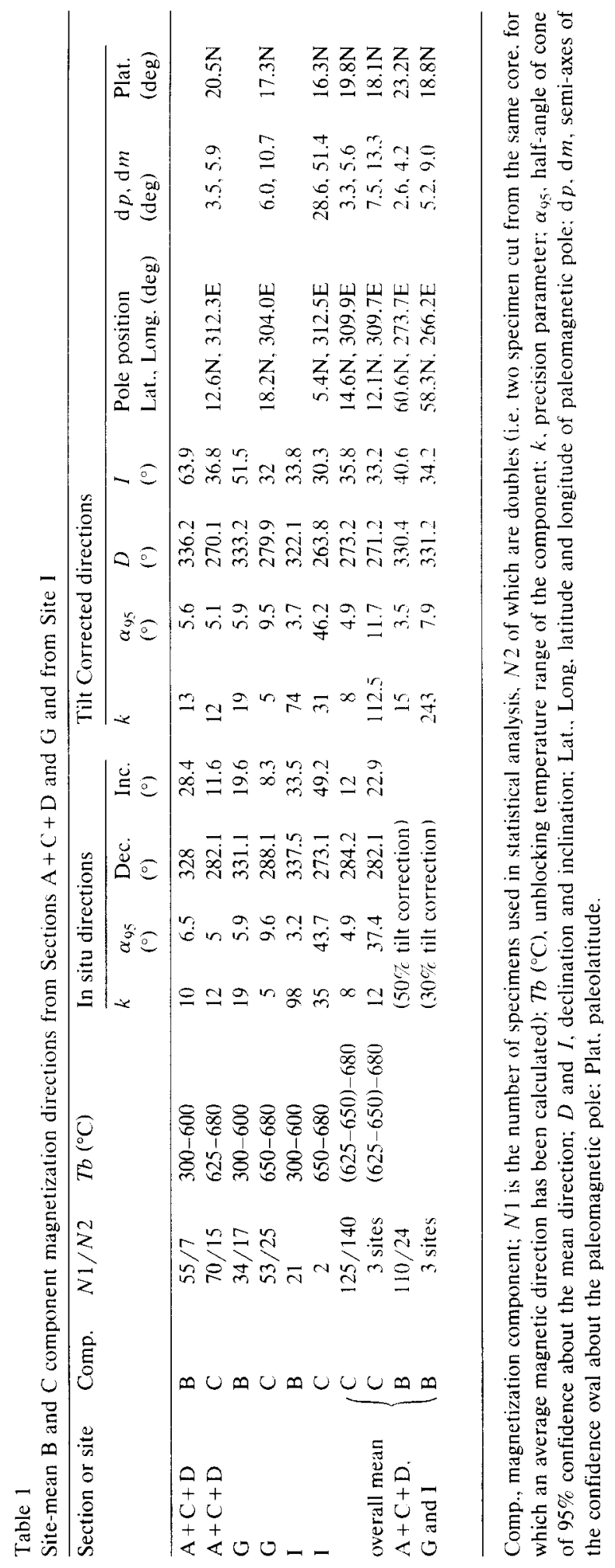


method of Lowrie (1990) typically reveals the presence of a dominant high-coercivity $-680^{\circ} \mathrm{C}$ maximum unblocking temperature phase interpreted as hematite (Fig. 8), a conclusion consistent with the high maximum unblocking temperatures of NRM and the pervasive reddish pigmentation of the Marmarotrapeza Formation. Lower coercivity fractions of IRM that might be attributed to magnetite are comparatively very small.

\section{Magnetic stratigraphy}

The stratigraphic distribution of the $C$ component directions at Sections $A+C+D$ and $G$ delineates three magnetic polarity zones. The polarity option chosen (i.e. northwest and down is normal) and the derived paleolatitude of about $18^{\circ} \mathrm{N}$ are compatible with the paleogeographic reconstruction of the western Tethys by Marcoux et al. (1993), in which the Serbo-Pelagonian zone, to which Chios belongs, is located between 10 and $20^{\circ} \mathrm{N}$ during the Middle Triassic. The polarity zones in ascending stratigraphic order have been labeled as Chios $\mathrm{A}^{+}$(normal), Chios $\mathrm{B}^{-}$ (reversed) and Chios $\mathrm{C}^{+}$(normal). Two of them, Chios $\mathrm{A}^{+}$and Chios $\mathrm{C}^{+}$, lack the base and the top, respectively, but Chios $\mathrm{B}^{-}$is fully defined (Fig. 3). The Chios $\mathrm{A}^{+}-$Chios $\mathbf{B}^{-}$boundary occurs at the base of a centimeter-thick condensed horizon at Sections $\mathrm{A}+\mathrm{C}+\mathrm{D}$ and $\mathrm{G}$. The overlying Chios $\mathrm{B}^{-}-$Chios $\mathrm{C}^{+}$boundary is less well defined: at Section $A+C+D$ it is affected by a minor fault, and at Section $G$ occurs at the base of a centimeter-thick hard ground (Fig. 3). However, paleontological observations suggest that the condensed horizons and the hard grounds do not seem to encompass large hiatuses.

The time interval covered by the Marathovouno sections is a matter of debate. According to the Mesozoic time scale of Gradstein et al. (1994), the duration of the Olenekian (late Early Triassic) is $3.1 \mathrm{~m} . \mathrm{y}$. and the Anisian is $7.4 \mathrm{~m} . \mathrm{y}$. If the Olenekian has two ammonoid zones (Kummel, $1973 a, b)$ whereas seven zones are currently recognized in the Anisian (Gaetani et al., 1992; Gaetani, 1993; Brack and Rieber, 1993) of the west- ern Tethys, the duration of the Marmarotrapeza Fm. in which no more than two zones are present can be roughly estimated at 2.5 m.y., yielding a sedimentation rate of about $7 \mathrm{~m}$ (m.y.) $)^{-1}$. Chios $\mathrm{B}^{-}$, with a thickness of about $4 \mathrm{~m}$, for example, should thus be about 0.57 m.y. long, and the average sampling density of $25-30 \mathrm{~cm}$ results in a nominal temporal resolution of about $40 \mathrm{k} . \mathrm{y}$. The directional excursions close to the Chios $\mathrm{A}^{+}$ Chios $\mathrm{B}^{-}$boundary at Section $\mathrm{A}+\mathrm{C}+\mathrm{D}$ could either reflect a very short polarity subchron or a localized remagnetization in the Chios $\mathrm{B}^{-}$field.

\section{Position of the Lower-Middle Triassic bound- ary}

The biochronology of Triassic pelagic limestones is mainly based on ammonoids and conodonts. As far as the ammonoids are concerned, the studied sections yielded only two Tethyan zones. The Spathian (uppermost substage of the Olenekian) Prohungarites-Subcolumbites zone of Kummel (1973a,b), recognized at the Marathovouno hillock by Assereto et al. (1980), ranges through magnetic polarity intervals Chios $\mathrm{A}^{+}$and Chios $\mathrm{B}^{-}$, and extends to the base of Chios $\mathrm{C}^{+}$ where some specimens of Preflorianites sp. are present, whereas an assemblage with Aegeiceras ugra (Diener), Paracrochordiceras spp., Paradanubites depressus Fantini Sestini and Japonites sp., referred to as Aegeiceras-Japonites beds (Gaetani et al., 1992), characterizes most of polarity interval Chios $\mathrm{C}^{+}$(Fig. 3). Concerning conodont biostratigraphy, Neospathodus homeri (Bender) ranges through Chios $\mathrm{A}^{+}$and Chios $\mathrm{B}^{-}$, whereas the First Appearance Datum (FAD) of Gondolella timorensis (Nogami) falls within the uppermost part of Chios $\mathrm{B}^{-}$and the FAD of Gondolella regalis (Mosher) is well within Chios $\mathrm{C}^{+}$(Fig. 3). At the Marathovouno sections, the FAD of $G$. timorensis thus slightly predates the first occurrence of the Aegeiceras-Japonites beds. In Gaetani et al. (1992), the position of the Lower-Middle Triassic boundary was nevertheless placed at the base of this ammonoid assemblage mainly for the two following reasons:

(1) the ammonoid assemblage probably marks 
In situ
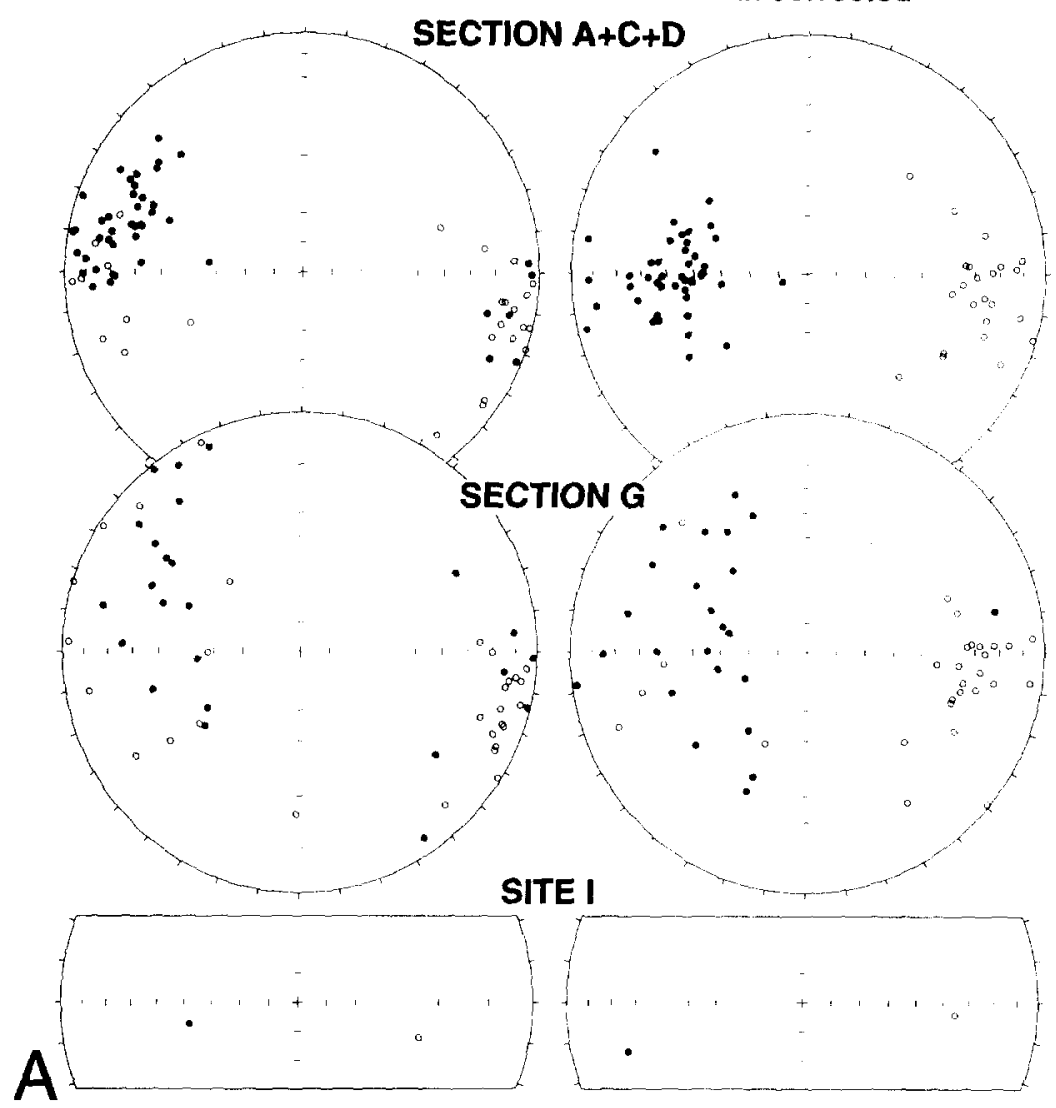

- (o) positive (negative) mean direction section of $A+C+D$

- (A) positive (negative) mean direction of section $\mathrm{G}$
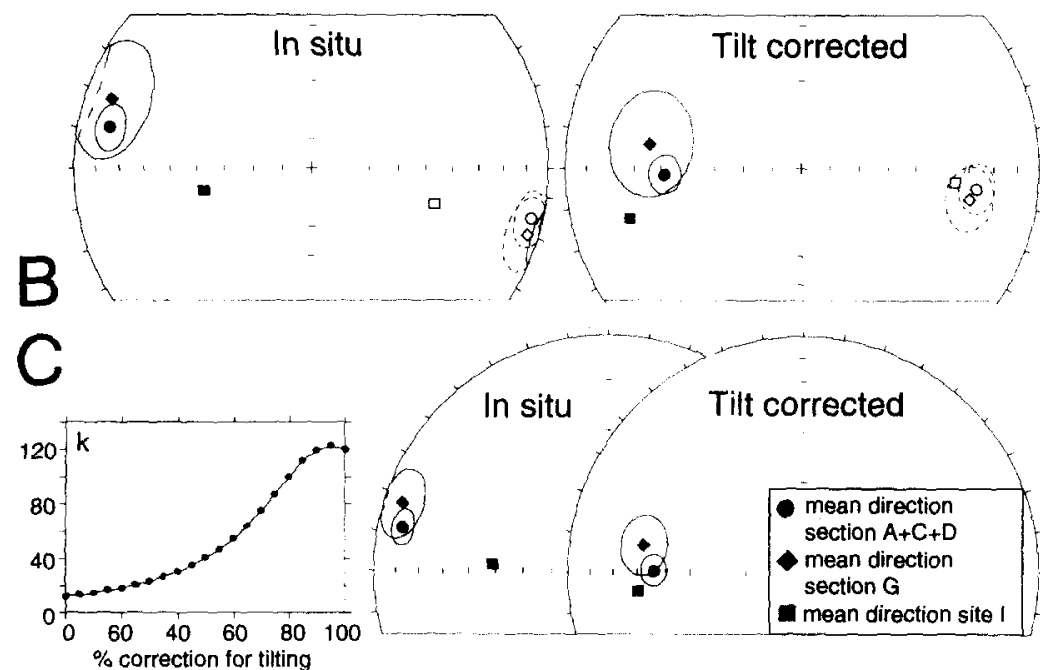

Fig. 7. Equal-area projections before (in situ) and after bedding tilt correction of (A) the characteristic $\mathrm{C}$ component directions from Sections $A+C+D$ and $G$, and Site $I,(B)$ site-mean characteristic directions from Sections $A+C+D$ and $G$, together with two specimens from Site $I$, and $(C)$ site-mean characteristic directions from Sections $A+C+D$ and $G$, and Site $I$, with variation in $k$ value with incremental unfolding. 
a real change in ammonoid evolution. Several Anisian genera first appear, whereas most typical Spathian forms are absent. The Aegeiceras ugra, Paracrochordiceras spp., Paradanubites depressus and Japonites sp. assemblage is the oldest so far described in Anisian sections, and is considered coeval with the $J$. welteri horizon of Nevada (Bucher, 1989). A similar assemblage characterizes the lowermost Anisian of Oman (Tozer and Talon, 1990) and of Dobrudgea (Romania). In the latter, Gradinaru (1991) reported the presence of a fossiliferous horizon referred to as Aegeiceras beds, containing Aegeiceras ugra, Japonites welteri Bucher, Procladiscites sp., Sturia sp., Metadagnoceras sp. and Leiophyllites sp. In the central part of the Tethys, ammonoids of this assemblage are present in the so-called mixed fauna described by Wang (1985).

(2) For historical reasons, in Triassic stratigraphy an ammonoid-based boundary is preferred to a conodont-based boundary, if the two are not coincident.

The presence of the $\mathrm{B}^{-}-\mathrm{C}^{+}$polarity reversal boundary between the FAD of $G$. timorensis and the Aegeiceras-Japonites beds sensu Gaetani et al. (1992) introduces a new and significant element in the definition of the base of the Anisian. We suggest that the base of the Anisian should be maintained at the first occurrence of the ammonoid stock, keeping in mind that the FAD of G. timorensis and the $\mathrm{B}^{-}-\mathrm{C}^{+}$boundary slightly predate it. This allows the use of the FAD of $G$. timorensis and the $\mathrm{B}^{-}-\mathrm{C}^{+}$boundary to approximate the base of the Anisian in those sections where ammonoids are not present.

\section{Magnetostratigraphic correlations}

To place the Chios magnetostratigraphic sequence in a broader context, we compare and attempt to correlate it with available Early and Middle Triassic magnetostratigraphies which have been worked out in various regions of the world in either marine or continental successions (Fig. 9). The Early Triassic is well studied. Among the nonmarine and marine sections shown in Fig. 9,
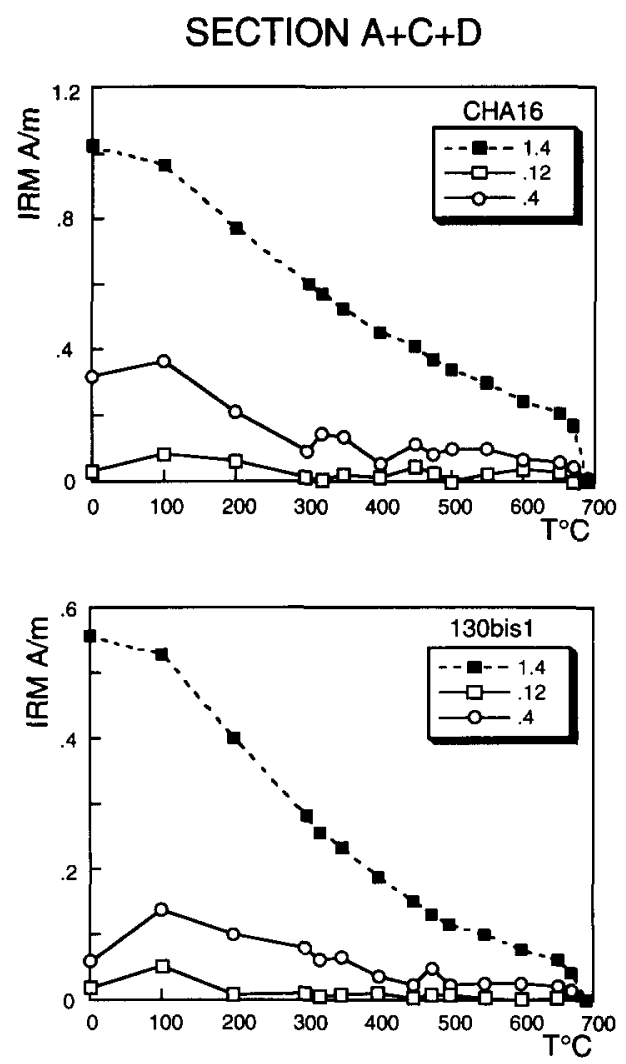

Fig. 8. Thermal decay of three-axis IRM for two Marmarotrapeza Fm. samples. IRM was obtained by applying a $1.4 \mathrm{~T}$ field along $z$-axis, $0.4 \mathrm{~T}$ along $x$-axis and $0.12 \mathrm{~T}$ along $y$-axis.

the ammonoid-bearing Arctic Archipelago composite section of Ogg and Steiner (1991) has been regarded by Lozovsky and Molostovsky (1993) as the standard for the Early Triassic Boreal marine environment. However, the overall correlation of polarity records of nonmarine Russia (Lozovsky and Molostovsky, 1993) and the Western USA (Steiner et al., 1993), and the marine Arctic (Ogg and Steiner, 1991) and South China (Steiner et al., 1989) is not unique in detail, as the different correlations attempted by Lozovsky and Molostovsky (1993) and Steiner et al. (1993) demonstrate. Lozovsky and Molostovsky's (1993) correlation is preferred in this paper, essentially because it summarizes more recent work on the Russia sequence.

Biostratigraphic correlation between Chios and South China should be the most feasible, as they 
belong to the same faunistic (Tethys) realm. Unfortunately, the $900 \mathrm{~m}$ Early Triassic carbonate sequence (composed of the Feixianguan and the overlying Jialingiiang Fms.) of the South China section (Section HPT of Steiner et al., 1989) lacks ammonoids. A conodont fauna diagnostic of the Griesbachian stage is present in the lowest $100 \mathrm{~m}$ of the Feixianguan Fm., whereas conodonts typical of a generic Smithian-Spathian age have been found in the overlying Jialingjiang Fm. Within these broad and incomplete biostratigraphic constraints, which seem to suggest that the South China sequence does not reach the top of the Spathian, it is possible that the uppermost normal polarity interval in the China section may correlate (in part) with Chios $\mathrm{A}^{+}$(Fig. 9).

With regard to biostratigraphic correlations between Chios (Tethys realm) and the Arctic sections (Boreal realm), according to Bucher (1989) and Gaetani et al. (1992) the upper part of

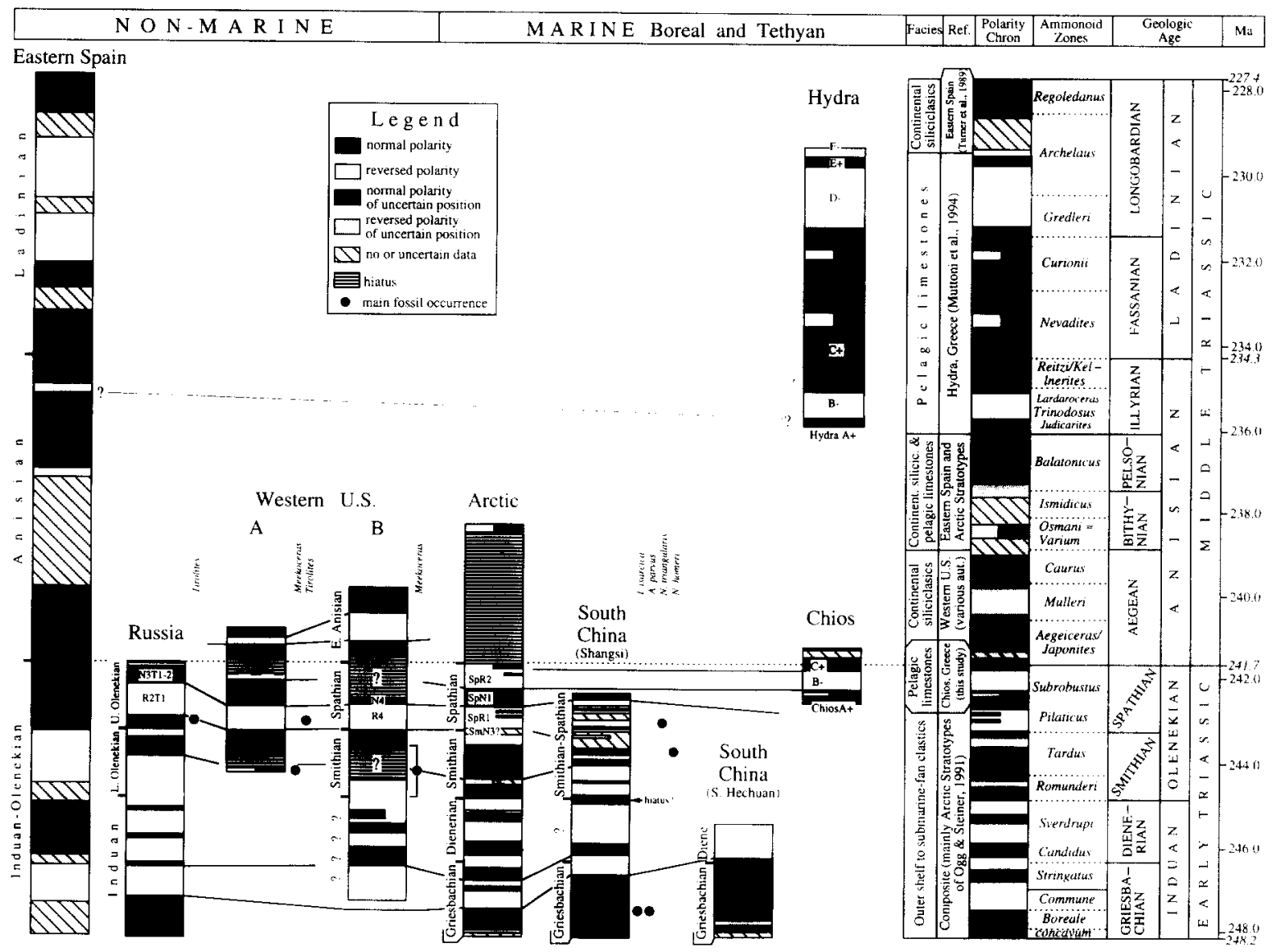

Fig. 9. Comparison of magnetic polarity sequences through the Early-Middle Triassic time interval. 'Eastern Spain' is the Bundsandstein and Muschelkalk composite section of Turner et al. (1989): 'Russia' is the Lower Triassic composite section from the Eastern European platform of Lozovsky and Malostovsky (1993); 'Western USA' is the Moenkopi Formation composite sections of Steiner et al. (1993) from the eastern (A) and western (B) parts of the sedimentary basin; 'South China (Hechuan)' is the HPT section of Steiner et al. (1989); 'South China (Shangsi)' is the South China section of Heller et al. (1988); 'Arctic' is the Canadian Arctic stratotypes composite section of Ogg and Steiner (1991); 'Chios' is the Marathovouno composite section of this study; 'Hydra' is the section from Hydra Island, Greece, of Muttoni et al. (1994). Tentative correlation of Early Triassic magnetostratigraphies after Lozovsky and Molostovsky (1993). Early Triassic ammonoid zones are from Ogg and Steiner (1991), and Middle Triassic ammonoid zones are from Brack and Rieber (1993), Gaetani (1993) and Tozer (1994). Numerical scale and stage boundaries are according to the Mesozoic time-scale of Gradstein et al. (1994). 
the Prohungarites-Subcolumbites zone of Chios containing Procladiscites and Preflorionites is correlative with the Haugi zone of Nevada, as well as with the Subrobustus zone of British Columbia, and the Aegeiceras-Japonites beds correspond, in Nevada, to the $J$. welteri beds. In British Columbia, this last level is not documented by ammonoids (Tozer, 1994). These paleontological observations lead us to conclude that Chios $\mathrm{A}^{+}$ and Chios $\mathrm{B}^{-}$magnetic polarity zones correlate, respectively, with polarity zones $\mathrm{SpN} 1$ and $\mathrm{SpR} 2$ of the Arctic stratotypes. On the other hand, the normal interval Chios $\mathrm{C}^{+}$does not have a secure correlative in the Arctic sections, where the presence of a hiatus affecting essentially the Aegean is indicated by the occurrence of the Middle Anisian Varium zone immediately above the Spathian Subrobustus zone (Fig. 9).

The poorly fossiliferous, mostly non-marine Moenkopi Fm. sections from the Western USA bear a discontinuous Smithian and Spathian ammonoid fauna. As Steiner et al. (1993) reported, the Smithian-Spathian boundary is here constrained by the presence of Meekoceras and Tirolites. Although biostratigraphic control of these sections is poor compared with the Chios section, the Chios polarity sequence may straddle a hiatus in the western Moenkopi Fm. composite sections (Fig. 9).

The Early Triassic composite section discussed for Russia (Eastern European platform) by Lozovsky and Molostovsky (1993) bears paleomagnetic zones that apparently correlate with those in the Western USA as well as the marine Arctic and South China sequences. With respect to Chios, the youngest normal polarity zone of the upper Olenekian $\left(\mathrm{N}_{3} \mathrm{~T}_{1-2}\right)$ may be correlative with Chios $\mathrm{A}^{+}$(Fig. 9).

The Chios magnetobiostratigraphy thus extends the Arctic standard marine sequence for the Early Triassic (as well as the marine sequence of South China and the nonmarine sequence of Russia) into the earliest Anisian, and perhaps bridges the gap across the Spathian to Early Anisian unconformity in the Western US nonmarine sections.

Magnetic polarity stratigraphy referred to the later Aegean to Pelsonian interval of the Anisian essentially comes from generally poorly dated continental successions (Eastern Spain and Western USA). An Early-Middle Triassic magnetostratigraphy from the Bundsandstein (continental conglomerates and sandstones) and Muschelkalk (marine carbonates) of the Iberian Cordillera, Eastern Spain (Turner et al., 1989) largely lacks biostratigraphic control, so that precise correlation to stage boundaries in general or to the conodont and/or ammonoid-bearing Chios section in particular is hardly possible. Moreover, the poor magnetostratigraphic resolution of the Eastern Spain section is apparent in the few polarity intervals delineated in the Lower Triassic compared with the Arctic and other sequences (Fig. 9). The lower Anisian portions of the Western US sections summarized by Steiner et al. (1993) do, however, consistently show a normalreversed-normal polarity sequence. The older normal interval most probably correlates with Chios $\mathrm{C}^{+}$, and hence there should be a reversed interval in the Anisian (shown in the Aegean in Fig. 9). Concerning the Bithynian-Pelsonian, the polarity stratigraphy is represented by only the poorly resolved and virtually unfossiliferous Eastern Spain section, where a reversed interval of unknown extension seems to be present. $\mathrm{Re}$ versed polarity is also indicated above the unconformity in the Arctic section.

There is thus a gap in the marine magnetostratigraphic record between the Olenekianearly Anisian of the Chios and Arctic sections, and the late Anisian (Illyrian)-late Ladinian (Longobardian) Hydra section from Greece (Muttoni et al., 1994). The Hydra section does not reach the top of the Longobardian, whose polarity attribution is tentatively inferred from the Eastern Spain section.

\section{Paleogeographic and tectonic interpretation}

To constrain the paleogeographic affinities of Chios, paleopoles for the syn-folding B component and the characteristic $\mathrm{C}$ component (Table 1) are compared with the apparent polar wander path (APWP) for stable Europe and for West 


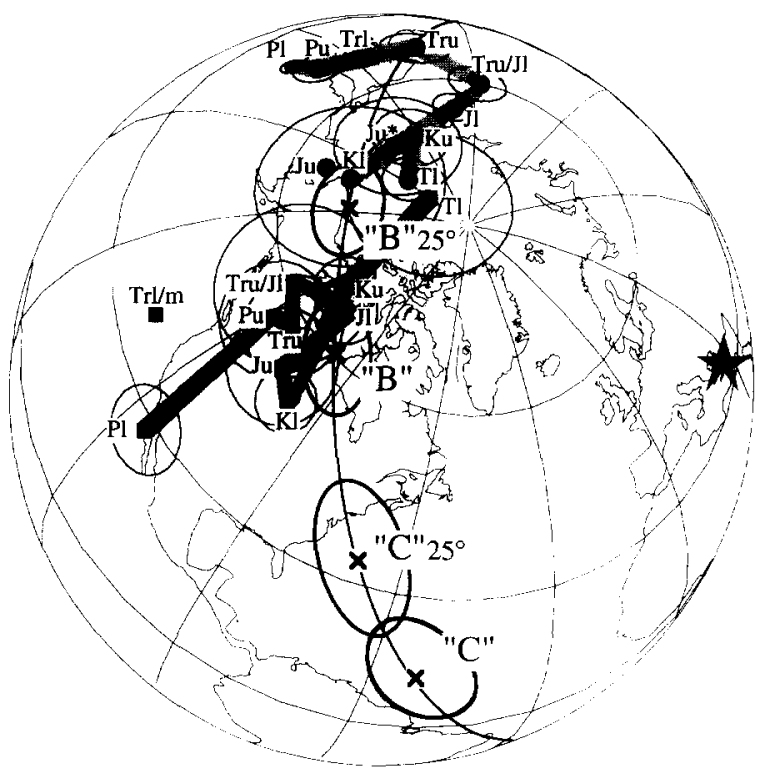

Fig. 10. Apparent polar wander paths for stable Europe (•) and for West Gondwana in northwest African coordinates (a) from compilation of van der Voo (1993), compared with the poles calculated from the $\mathrm{B}$ and $\mathrm{C}$ components isolated at the Marathovouno sections. ' $\mathrm{B}$ ' $25^{\circ}$ and ' $\mathrm{C}$ ' $25^{\circ}$ are the $\mathrm{B}$ and $\mathrm{C}$ paleopoles restored for Neogene $25^{\circ}$ counter-clockwise rotation inferred by Kondopoulou et al. (1993). The small circle through the ' $\mathrm{B}$ ' and ' $\mathrm{C}$ ' poles is the average paleocolatitude calculated from the $\mathrm{B}$ and $\mathrm{C}$ component paleolatitudes, and represents the expected locus of paleopoles resulting from tectonic rotations about a local vertical axis on Chios. Age symbols: Pl, Lower Permian; Pu, Upper Permian; Trl/m, Lower-Middle Triassic; Tru, upper Middle Triassic-Upper Triassic; Tru/Jl, Upper Triassic-Lower Jurassic; Jl, Lower Jurassic; IJm, lower Middle Jurassic; Ju, Upper Jurassic; Kl, Lower Cretaceous; Ku, Upper Cretaceous; Tl. Lower Tertiary.

Gondwana or 'Africa' (Africa and South America, in northwest Africa coordinates) according to the recent review of Van der Voo (1993) (Fig. $10)$.

The B component is significantly better grouped at partial rather than full tilt correction and is hence considered an overprint acquired when the beds were already partly tilted. The paleopole calculated from the $30 \%$ untilted direction falls close to 'African' Mesozoic poles, but approaches Late Mesozoic and Cenozoic poles for stable Europe if $25^{\circ}$ of Neogene counterclockwise rotation inferred by Kondopoulou et al.
(1993) is taken into account. A possible interpretation for the acquisition of the $\mathrm{B}$ component is that it was acquired during the Hellenic tectonic cycle (i.e. Late Cretaceous to Eocene) and was then rotated during the Anatolian cycle in the Neogene. Assuming normal polarity for the B component, the derived paleolatitude of about $19^{\circ} \mathrm{N}$ is broadly compatible with either an 'African' or stable European affinity, or somewhere between the colliding margins of Africa and Europe.

The C component paleopole of probable Early-Middle Triassic boundary age shows a large counter-clockwise rotation with respect to Triassic paleopoles from 'Africa' and stable Europe. The differences in arc distance are about $111^{\circ}$ and $67^{\circ}$, respectively, and reduce to about $88^{\circ}$ and $43^{\circ}$ if restored for the $25^{\circ}$ of Neogene counterclockwise rotation inferred by Kondopoulou et al. (1993). The paleolatitude of $18^{\circ} \mathrm{N}$ is compatible with either 'African' or stable European affinity. It is therefore difficult to state on the basis of paleomagnetic evidence if Chios was connected to stable Europe or to 'Africa' during the Triassic. The Serbo-Pelagonian zone is generally considered a south Tethyan microplate that rifted off the northern margin of Gondwana during the Triassic, and hence should have an 'African' affinity at least for pre-rifting times (Channell and Horváth, 1976; Dixon and Robertson, 1984; Mountrakis et al., 1987). The large pre-B component rotation with respect to 'Africa' and stable Europe may therefore represent paleomagnetic evidence of the Serbo-Pelagonian microplate rifting as Chios moved independently of both plates.

\section{Conclusions}

Tethyan pelagic limestones sampled at Sections $\mathrm{A}+\mathrm{C}+\mathrm{D}$ and $\mathrm{G}$ from Marathovouno on Chios (Greece) provide a consistent magnetic polarity stratigraphy which can be correlated with the Olenekian-Anisian (Lower-Middle Triassic) boundary based either on conodonts or Tethyan ammonoids. The base of the Anisian on the basis of ammonoids slightly post-dates the base of nor- 
mal polarity interval Chios $\mathrm{C}^{+}$. An assessment of available Early and Middle Triassic magnetobiostratigraphies suggests that the Chios record extends the Arctic standard marine sequence for the Early Triassic into the earliest Anisian, but a gap remains to be filled in the marine magnetostratigraphic record of the Middle Triassic until the late Anisian (Illyrian). A minimum of 28 polarity intervals can be tentatively recognized in the Early-Middle Triassic which, according to Gradstein et al. (1994), lasted about 21 m.y. This implies a (minimum) reversal rate of about 1.3 reversals per m.y. and an average polarity duration of about 0.75 m.y., statistics comparable with those commonly accepted for the Late Cretaceous and Early Cenozoic.

Paleomagnetic data from the Marathovouno sections suggest large counter-clockwise rotations with respect to either 'Africa' or stable Europe. Rotation apparently occurred between the Early-Middle Triassic (age of the characteristic C component) and the Late Cretaceous-Eocene (presumed age of the secondary B component), and also in the Neogene (Kondopoulou et al., 1993). The earlier rotation might indicate that Chios moved independently of both 'Africa' and stable Europe, perhaps as a consequence of Serbo-Pelagonian microplate rifting, whereas the later rotation may be related to the complex history of local tectonic rotations that, according to Kissel et al. (1987), affected western Anatolia in the Neogene.

\section{References}

Assereto, R., 1974. Aegean and Bithynian: proposal for two new Anisian substages. Schrift. Erdwiss. Komm., 2: 23-39.

Assereto, R., Jacobshagen, V., Kauffmann, G. and Nicora, A., 1980. The Scythian/Anisian boundary in Chios, Greece. Riv. Ital. Paleontol. Stratigr., 85(1979): 715-736.

Bender, H., 1970. Der Nachweiss von Unter-Anis ("Hydasp") auf der Insel Chios. Ann. Géol. Pays Hell., 19(1967): 412-467.

Besenecker, H., Dürr, S., Herget, G., Kauffmann, G., Lüdtke, G., Roth, W. and Tietze, K.W., 1968. Geologie von Chios (Ägäis). Ein Überblik. Geol Palaeont., 2: 121-150.

Besenecker, H., Dürr, S., Herget, G., Kauffmann, G., Lüdtke,
G., Roth, W. and Tietze, K.W., 1971. Geological map of Greece, 1:50000, Chios sheet (northern and southern parts). Inst. Geol. Subsurface Res. (IGME), Athens.

Brack, P. and Rieber, H., 1993. Towards a better definition of the Anisian/Ladinian boundary: new biostratigraphic data and correlations of boundary section from the Southern Alps. Eclogae Geol. Helv., 86(2): 415-527.

Bucher, H., 1989. Lower Anisian ammonoids from the northern Humboldt Range (northwestern Nevada, USA) and their bearing upon the Lower-Middle Triassic boundary. Eclogae Geol. Helv., 82: 945-1002.

Channell, J.E.T. and Horváth, F., 1976. The African/Adriatic promontory as a paleogeographical premise for alpine orogeny and plate movements in the Carpatho-Balkan region. Tectonophysics, 35: 71-101.

Dixon, J.E. and Robertson, A.H.F. (Editors), 1984. The geological evolution of the Eastern Mediterranean. Geol. Soc. Spec. Publ., 17, 824 pp.

Fantini Sestini, N., 1981. Lower Anisian (Aegean) ammonites from Chios Island (Greece). Riv. Ital. Paleontol. Stratigr., 87: $41-66$.

Fytikas, M., Innocenti, F., Manetti, P., Mazzuoli, R., Peccerillo, A. and Villari, L., 1984. Tertiary to Quaternary evolution of volcanism in the Aegean region. Geol. Soc. Spec. Publ., 17: 687-699.

Gaetani, M., 1993. Anisian/Ladinian boundary field workshop, Southern Alps-Balaton Highlands, 27 June-4 July 1993. Albertiana, 12: 5-9.

Gaetani, M., Jacobshagen, V., Nicora, A., Kauffmann, G., Tselepidis, V., Fantini Sestini, N., Mertmann, D. and Skourtsis-Coroneou, V., 1992. The Early-Middle Triassic boundary at Chios. Riv. Ital. Paleontol. Stratigr., 98(2): $181-204$.

Gradinaru, E., 1991. An integrated biostratigraphy of the Spathian/Lower Anisian boundary in North Dubrogea (Romania): a test case for the Tethyan biostratigraphy. Symp. on Triassic Stratigraphy, Lausanne, 20-23 October 1991.

Gradstein, F.M., Agterberg, F.P., Ogg, J.G., Hardenbol, J., van Veen, P., Thierry, J. and Huang, Z., 1994. A Mesozoic time scale. J. Geophys. Res., 99: 24051-24074.

Heller, F., Lowrie, W., Huamei, L. and Junda, W., 1988. Magnetostratigraphy of the Permo-Triassic boundary section at Shangsi (Guangyuan, Sichuan Province, China). Earth Planet. Sci. Lett., 88: 348-356.

Jacobshagen, V., Dürr, St., Kockel, F., Kopp, K.-O. and Kowalczyk, G., with contributions of Berckhemer, H. and Büttner, D., 1978. Structure and geodynamic evolution of the Aegean region. In: H. Closs, D.H. Roeder and K. Schmidt (Editors), Alps, Apennines, Hellenides. Union Comm. Geodynamics, Sci. Rep., 38. E. Schweizerbart'sche Verlagsbuchhandlung, Stuttgart, pp. 537-564.

Kirschvink, J.L., 1980. The least squares line and plane and analysis of paleomagnetic data. Geophys. J. R. Astron. Soc., 45: 699-718.

Kissel, C., Laj, C., Sengör, A.M.C. and Poisson, A., 1987. Paleomagnetic evidence for rotation in opposite senses of 
adjacent blocks in northeastern Aegean and western Anatolia. Geophys. Res. Lett., 14: 907-910.

Kondopoulou, D., Sen, S., Koufos, G. and de Bonis, L., 1993. Paleomagnetic data from the Miocene of the Island of Chios, Greece. Terra Nova, 5 (Abstr. Suppl. 1).

Kummel, B, 1973a. Lower Triassic (Scythian) molluscs. In: A. Hallam (Editor), Atlas of Palaeobiogeography. Elsevier, Amsterdam, pp. 225-233.

Kummel, B., 1973b. Aspects of the Lower Triassic (Scythian) stage. Can. Soc. Petrol. Geol. Mem., 2: 557-571.

Lazzaroni, R., 1991. Rilevamento della successione Triassica nell'area dello strato tipo Egeico (Chios; Grecia). Sottotesi Univ. Milano, $40 \mathrm{pp}$.

Lowrie, W., 1990. Identification of ferromagnetic minerals in a rock by coercivity and unblocking temperature properties. Geophys. Res. Lett., 17: 159-162.

Lozovsky, V.R. and Molostovsky, E.A., 1993. Constructing the Triassic magnetic polarity time scale. N.M. Mus. Nat. Hist. Sci. Bull., 3: 297-300.

Marcoux, J., Baud, A., Ricou, L.E., Gaetani, M., Krystyn, L., Bellion, Y., Guiraud, R., Moreau, C.. Besse, J., Gallet, Y. and Thieveniaut, H., 1993. Late Anisian (237 to $234 \mathrm{Ma}$ ). In: J. Dercourt, L.E. Ricou and B. Vrielynck (Editors), Atlas Tethys Palaeoenvironmental Maps. Explanatory Notes. Gauthier-Villars, Paris, pp. 113-134.

McFadden, P.L. and Jones, D.L., 1981. The fold test in palaeomagnetism. Geophys. J. R. Astron. Soc., 67: 53-58.

McFadden, P.L. and McElhinny, M.W., 1990. Classification of the reversal test in palaeomagnetism. Geophys. J. Int., 103: $725-729$.

Mountrakis, D., Patras, D., Kilias, A., Pavlides, S. and Spyropoulos, N., 1987. Structural geology of the Internal Hellenides and their role to the geotectonic evolution of the Eastern Mediterranean. Acta Nat. Ateneo Parmense, 23: $147-162$.

Muttoni, G. and Rettori, R., 1994. New biostratigraphic data on the Triassic of the Marathovouno hillock area (Chios Island, Greece). Riv. Ital. Paleontol. Stratigr., 99(4, 1993): 461-472.

Muttoni, G., Channell, J.E.T., Nicora, A. and Rettori, R.,
1994. Magnetostratigraphy and biostratigraphy of an Anisian-Ladinian (Middle Triassic) boundary section from Hydra (Greece). Palaeogeogr. Palaeoclimatol. Palaeoecol., 111: 249-262.

Ogg. J.G. and Steiner, M., 1991. Early Triassic magnetic polarity time scale-integration of magnetostratigraphy, ammonite zonation and sequence stratigraphy from stratotype sections (Canadian Arctic Archipelago). Earth Planet. Sci. Lett., 107: 69-89.

Renz, C. and Renz, O., 1948. Eine untertriadische Ammonitenfauna von der griechischen Insel Chios. Schweiz. Palaeontol. Abh., 66: 1-98.

Steiner, M., Ogg, J., Zhang, Z. and Sun. S., 1989. The Late Permian/Early Triassic magnetic polarity time scale and plate motions of South China. J. Geophys. Res., 94: 73437363.

Steiner, M., Morales, M. and Shoemaker, E.M., 1993. Magne tostratigraphic, biostratigraphic and lithologic correlations in Triassic strata of the Western United States. In: D.M. Aïssaoui, D.F. McNeill and N.F. Hurley (Editors), Applications of Paleomagnetism to Sedimentary Geology. Soc. Econ. Paleontol. Mineral. Soc. Sediment. Geol., 49: 41-57.

Tozer, E.T., 1994. Canadian Triassic ammonoid faunas. Geol. Surv. Can. Bull., 467, 663 pp.

Tozer, E.T. and Talon, T.J., 1990. Triassic ammonoids from Jabal Safra and Wadi Alwa, Oman, and their significance. Geol. Soc. Spec. Publ., 49: 203-211.

Turner, P., Turner. A., Ramos, A. and Sopena, A., 1989. Paleomagnetism of Permo-Triassic rocks in the Iberian Cordillera. Spain: acquisition of secondary and characteristic remanence. J. Geol. Soc. London, 14: 61-76.

Van der Voo, R., 1993. Paleomagnetism of the Atlantic. Tethys and Iapetus Oceans. Cambridge University Press, Cambridge, $411 \mathrm{pp}$.

Wang, Y.. 1985. Remarks on Scythian/Anisian boundary. Riv. Ital. Paleont. Stratigr., $90(1984): 515-544$.

Zanchi. A., Kissel, C. and Tapirdamaz, C.. 1990. Deformazione continentale neogenico-quaternaria in Anatolia occidentale: nuovi dati strutturali. Mem. Soc. Geol. Ital.. 45: $481-488$. 